\title{
National Streamflow Information Program Implementation Status Report
}

\author{
... from the National Streamflow Information Program
}

This Fact Sheet is one in a series that highlights information or recent research findings from the USGS National Streamflow Information Program (NSIP). The investigations and scientific results reported in this series require a nationally consistent streamgaging network with stable long-term monitoring sites and a rigorous program of data collection, quality assurance, management, archiving, and synthesis. NSIP produces multipurpose, unbiased surface-water information that is readily accessible to all.

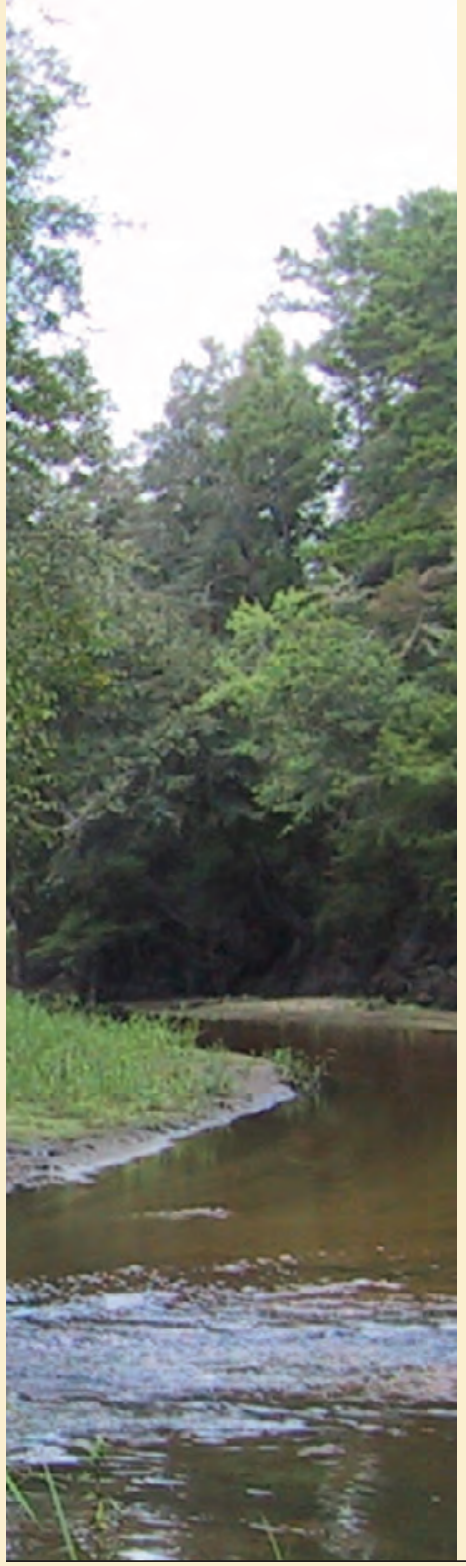

\section{Introduction}

The U.S. Geological Survey (USGS) operates and maintains a nationwide network of about 7,600 streamgages designed to provide and interpret long-term, accurate, and unbiased streamflow information to meet the multiple needs of many diverse national, regional, state, and local users. The National Streamflow Information Program (NSIP) was initiated in 2003 in response to Congressional and stakeholder concerns about (1) the decrease in the number of operating streamgages, including a disproportionate loss of streamgages with a long period of record;

(2) the inability of the USGS to continue operating high-priority streamgages in an environment of reduced funding through partnerships; and (3) the increasing demand for streamflow information due to emerging resource-management issues and new data-delivery capabilities. The NSIP's mission is to provide the streamflow information and understanding required to meet national, regional, state, and local needs.

Most of the existing streamgages are funded through partnerships with more than 850 other Federal, state, tribal, and local agencies. Currently, about 90 percent of the streamgages send data to the World Wide Web in near-real time (some information is transmitted within 15 minutes, whereas some lags by about 4 hours). The streamflow information collected at USGS streamgages is used for many purposes:

- In water-resource appraisals and allocations - to determine how much water is available and how it is being allocated;

- To provide streamflow information required by interstate agreements, compacts, and court decrees;

- For engineering design of reservoirs, bridges, roads, culverts, and treatment plants;

- For the operation of reservoirs, the operation of locks and dams for navigation purposes, and power production;

- To identify changes in streamflow resulting from changes in land use, water use, and climate;

- For streamflow forecasting, flood planning, and flood forecasting;

- To support water-quality programs by allowing determination of constituent loads and fluxes; and

- For characterizing and evaluating instream conditions for habitat assessments, instream-flow requirements, and recreation. 


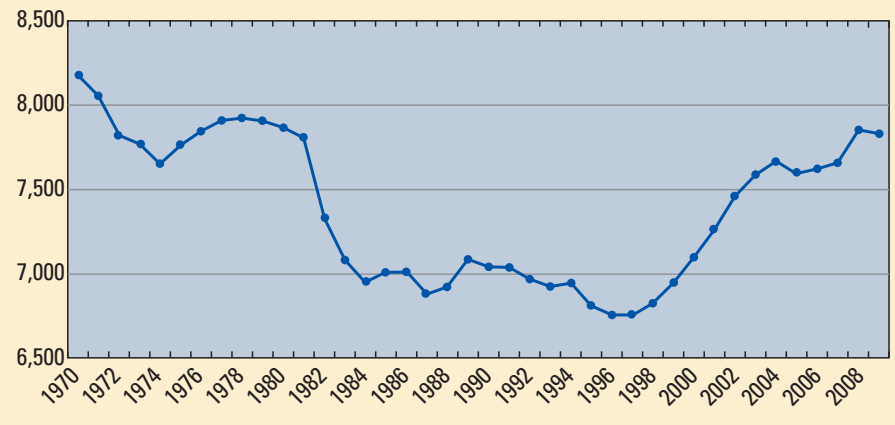

Figure 1. Number of active U.S. Geological Survey streamgages, 1970-2009.

\section{Streamgage-Network Instability}

The number of streamgages operated by the USGS over the past 40 years (fig. 1) has varied from a high of about 8,300 in 1970 to a low of about 6,800 in 1998. Over this 40-year period, the number of streamgages has decreased by more than 660 even though the need for streamflow information has increased due to increasing population, required habitat assessments, new water-quality requirements such as total maximum daily loads, and the need to understand the effects of climate change. The instability of the streamgage network over the past 40 years can also be illustrated by the loss of streamgages that had at least 30 years of information when they were discontinued (fig. 2). Data from long-record streamgages are critical for identifying changes in the amount and timing of streamflow caused by changes in land use, water use, and climate.

Much of the streamgage-network instability is directly attributable to variations in funding. For example, funding sources for the USGS streamgage network in fiscal year 2009 are shown in figure 3 . The USGS has direct control of only about 15 percent of the funds required to operate and maintain the network (the NSIP funds). The USGS contributes another 17 percent of the streamgage-network funding through the USGS Cooperative Water Program (CWP), which requires at least a 50-percent match from the cooperating partner for the USGS to invest the CWP funds for streamgaging. Funds from state and local agencies for streamgaging are not being matched dollar for dollar by the USGS CWP; those agencies are currently providing about $\$ 2.6$ for every $\$ 1$ provided by the CWP. Consequently, when partner funding is reduced, the water community often loses streamgages because there is inadequate funding to maintain them. As a result, the network's ability to meet long-term Federal needs for streamflow information is uncertain.

To respond to this issue, the USGS developed a plan for the National Streamflow Information Program (U.S. Geological Survey, 1999). This fact sheet briefly describes the current status of the NSIP and the progress that has been made in implementing the five goals outlined in the NSIP plan. Because the needs for and uses of streamflow information

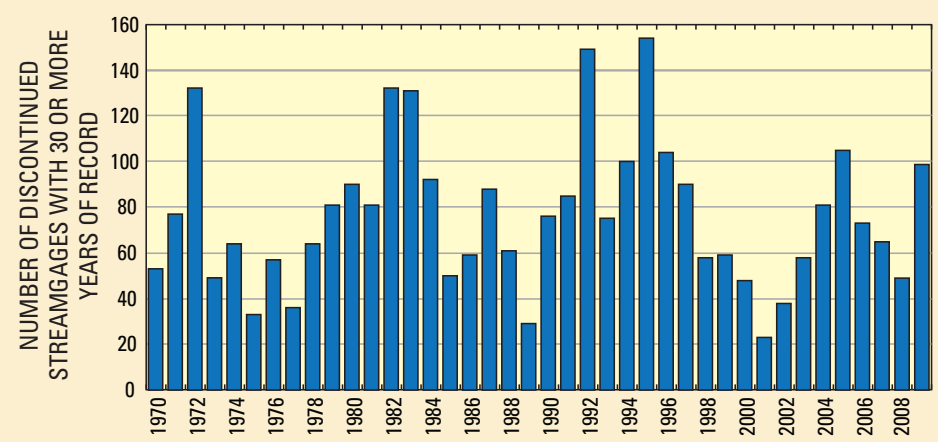

Figure 2. Number of discontinued U.S. Geological Survey streamgages with 30 or more years of record, 1970-2009. 


\section{Critical Federal Needs for Streamflow Information}

Five critical Federal needs for streamflow information that would be met by the core set of 4,744 USGSfunded streamgages in NSIP have been identified:

- Interstate and International Waters - Interstate compacts, court decrees, and international treaties mandate long-term, accurate, and unbiased streamgaging by the USGS at State-line crossings, compact points, and international boundaries.

\section{- Streamflow Forecasts-}

Real-time stage and discharge data are required to support flood and other streamflow forecasting by the National Weather Service and other Federal agencies across the country.

\section{- River Basin Outflows-}

Resource managers need to account for the contribution of water from each of the Nation's 350 major river basins to the next downstream basin or other receiving water body (estuary, Great Lake, or ocean).

\section{- Sentinel Watersheds-}

A network of streamgages is needed to document and evaluate streamflow characteristics in 800 watersheds across the country that are relatively unaffected by flow regulation or diversion and typify major ecoregions and river basins to determine effects of changes in land use, water use, and climate.

- Water Quality-Streamgaging stations are needed to provide the stream-discharge information in support of the three USGS national water-quality networks. Through these three networks, the USGS monitors and documents water quality in the Nation's streams, from the largest river basins to the smallest watersheds. of existing streamgages threatened with discontinuation rather than to fund new or reactivated streamgages.

\section{Objective 2}

Upgrade equipment at existing streamgages that do not currently have the capability to transmit data in real time, and upgrade to high data rate (HDR) transmitters at all streamgages.

The expected outcomes are that additional streamgages will deliver real-time information to the World Wide Web at shorter time intervals, and that compliance with the directive that all transmitters to the Geostationary Operational Environmental Satellite (GOES) be equipped with HDR transmitters by 2013 will be achieved.

Status. The USGS streamgage network currently (2009) is at about 90-percent real-time capability; nearly all of those streamgages are equipped with the new HDR transmitters.

\section{Objective 3}

Implement the NSIP network of federally funded streamgages as authorized in Public Law 111.11, for the operation and maintenance of a stable network of 4,756 streamgages. The NSIP network of federally funded streamgages to meet national needs would be in conjunction with partner-funded streamgages to meet additional state and local needs and make up the National Streamgage Network. The expected

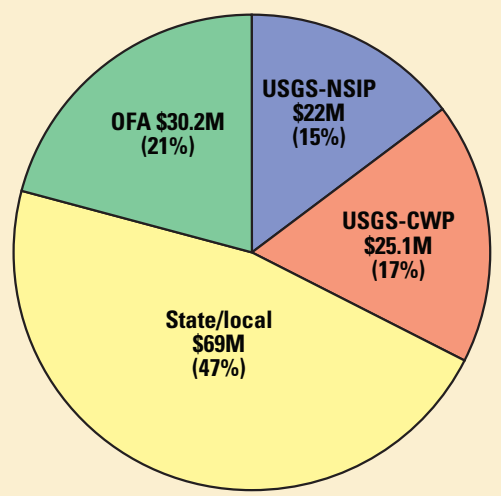

Figure 3. Funding sources for the U.S. Geological Survey streamgaging network, 2009. (Values are in millions of dollars; total funding \$146.3 million; OFA, other Federal agencies; NSIP, National Streamflow Information Program; CWP, Cooperative Water Program)

outcome is that NSIP funding for critical streamgages currently operated under the CWP or with other Federal agency funds would be secure and would ensure the uninterrupted delivery of critical streamflow information to meet Federal needs. Moreover, CWP and associated state and local funds released as a result of the NSIP funding of streamgages would be available to support additional streamgages to meet local needs and to supplement the core set of federally funded streamgages.

Status. Currently, 3,032 (64 percent) of the 4,756 NSIP "backbone" streamgages are operated year round by the USGS. NSIP currently fully funds

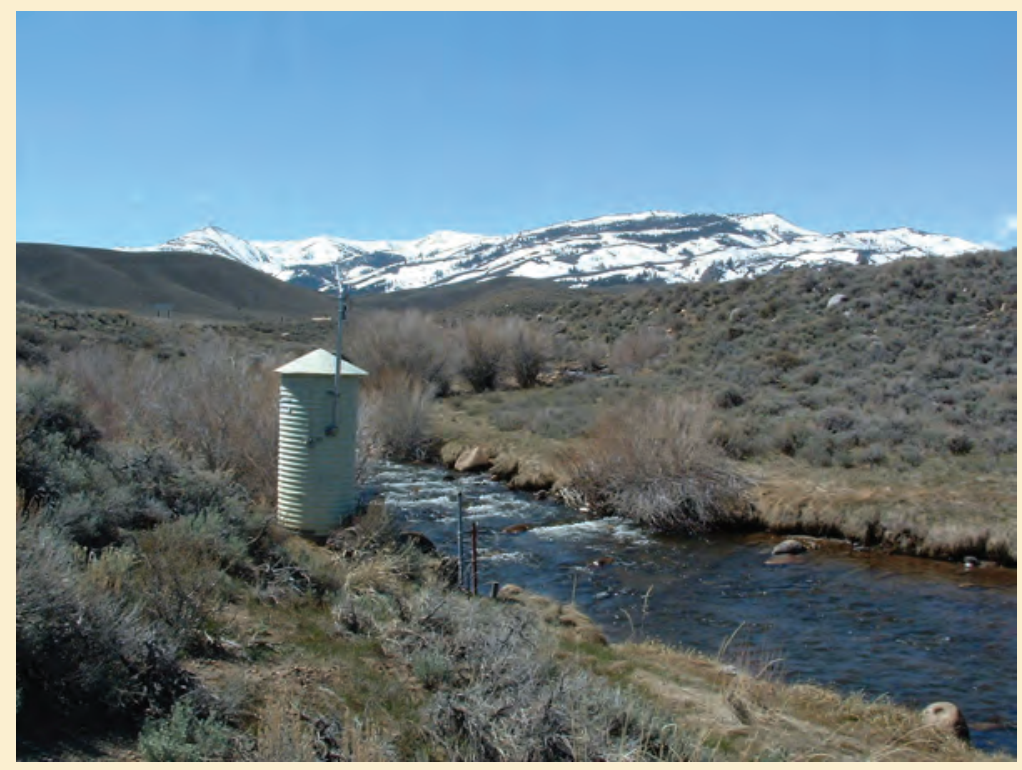

A typical U.S. Geological Survey streamgage, Little Walker River near Bridgeport, Nevada. 
only about 378 (12 percent) of these streamgages; NSIP shares costs with partners for another 965 streamgages (32 percent). The remaining 1,689 existing NSIP streamgages are completely funded by other Federal, State, tribal, and local agencies and the CWP. Nearly 1,200 additional streamgages, which will also require Federal NSIP funds to operate and maintain, remain to be added to complete the planned network.

\section{Objective 4}

Flood-harden streamgages at National Weather Service forecast locations to the 200-year-flood level to ensure that they continue to provide critical data during floods. The expected outcome is that approximately 3,600 streamgages used for forecasts would be flood hardened under full NSIP implementation.

Status. NSIP resources have not been sufficient to meet this objective to date, as all available resources have been invested in higher priority NSIP objectives. However, approximately 140 NSIP streamgages were flood-hardened with supplemental funding obtained as a result of Hurricanes Katrina and Rita.

\section{Objective 5}

Federally fund infrastructure costs of the entire national streamgage network. Supporting additional streamgages to meet state and local needs, funded through the CWP, adds little to overall infrastructure costs. These incremental added costs include those for activities such as national database development and maintenance, local database administration and project oversight costs, and the USGS Office of Surface Water, which provides technical guidance and oversight for all USGS surface-water activities at the national level.

Status. USGS Water Science Centers (WSCs) have been allowed to apply their NSIP funding allocation to this objective for several years, but the overwhelming percentage of WSC funding allocations are used to fund the operation and maintenance of NSIP Federal-goal streamgages. It is estimated that less than 10 percent of the allocated NSIP funds are used to help meet this objective.

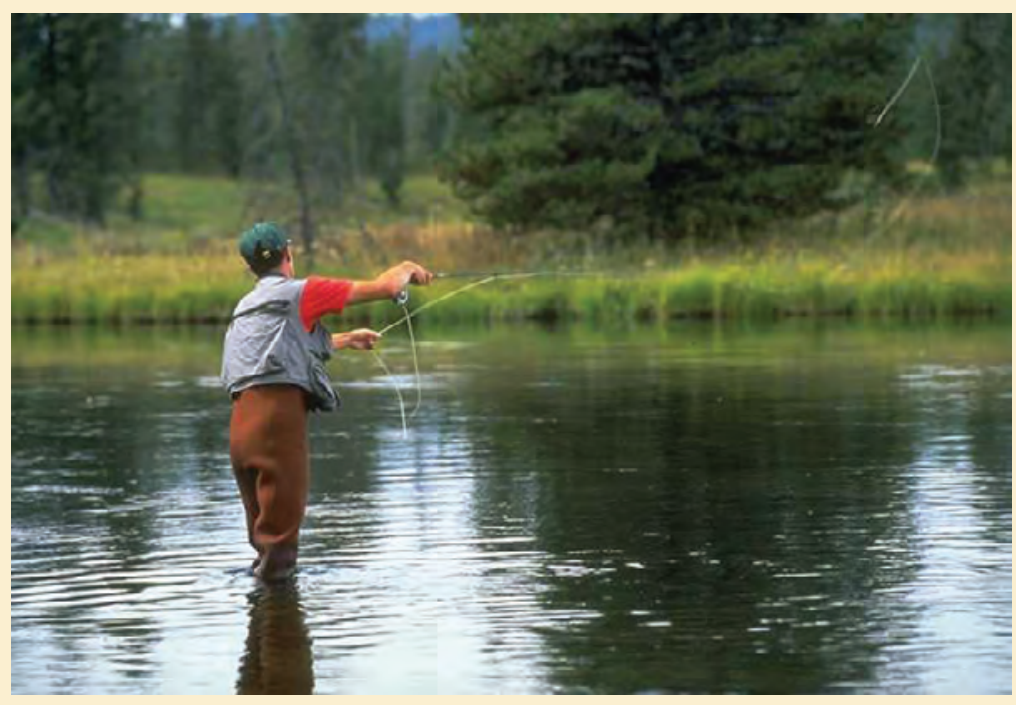

Recreating on a river. Streamflow information is used by many recreationists to help ensure a safe and enjoyable experience.

\section{Goal 2: Improved Delivery of Streamflow Data to Users}

Developing new, state-of-the-art methods to transmit, store, and distribute streamflow information is an essential component of the NSIP. Improving the delivery of streamflow data includes a wide spectrum of activities, such as the automatic transmission of data from the streamgage on the river bank into the database, analysis of the rating curve, and reporting of and access to the data on the World Wide Web. Also included is ensuring the information is available when needed by establishing backup data-delivery systems and providing enhanced data-storage, -retrieval, and -analysis capabilities.

\section{Objective 1}

Implement a system to help ensure uninterrupted delivery of streamflow information under all conditions.

Status. The USGS made this objective a high priority and was able to achieve it by implementing a national system of backup servers. All existing streamflow information, both real-time and historical, is available for the entire Nation 24 hours a day, 365 days a year, regardless of conditions. The USGS also worked with other Federal agencies to establish a back-up receiver site for satellite data transmissions through the GOES system at the Earth Resources Observation Systems (EROS), in South Dakota.

\section{Objective 2}

Develop enhanced systems and processes for quality assurance of streamflow information to provide highquality data in a timely and efficient manner. This objective includes the development of a process for the realtime quality assurance of streamflow information, as well as computer programs and techniques to more rapidly and cost effectively compute streamflow.

Status. The USGS has developed and implemented a system that automatically detects when a streamgage may be transmitting erroneous data and sends an e-mail notice to the responsible office for evaluation. A method to automatically correct erroneous data is planned. The USGS has developed numerous computer applications to assist hydrographers in processing raw streamflow information in order to reduce the time required to finalize the streamflow record.

\section{Objective 3}

Maximize the usefulness and accessibility of streamflow information to users of the information. This objective includes providing confidence intervals for the data, increasing the availability of instantaneous-value data, and developing new products to present the information.

Status. The USGS developed a database (Instantaneous Data Archive, or IDA), available through the World Wide Web, that currently (March 2011) contains more than 3 billion 
instantaneous values of streamflow information from 47 states. The USGS has also developed a powerful streamflow-information synthesis tool on the World Wide Web called WaterWatch. WaterWatch allows the user to compare real-time streamflow information with historic streamflow information to obtain a current assessment of hydrologic conditions. The ability to apply confidence intervals to the streamflow data has not yet been achieved.

\section{Goal 3: Regional Assessments of Streamflow Characteristics}

Although the USGS National Water Information System (NWIS) database contains billions of pieces of streamflow information, there has been no systematic process to evaluate and analyze those data. In cases where data have been analyzed, the effects of changes in land use, water use, and climate are commonly observed. Although the USGS currently operates about 7,600 streamgages, there are many more river reaches that are not measured; being able to estimate the streamflow at these ungaged locations is critical. In addition, for many uses of the data, trends in streamflow need to be identified. The NSIP's goal of regional assessments includes providing a means to estimate flow at ungaged locations, a mechanism for identifying trends in streamflow, and information required to assess the adequacy of the streamgage network.

\section{Objective 1}

Evaluate appropriate methods for utilizing streamflow information to perform regional streamflow assessments. These evaluations will be designed to (1) estimate streamflow at ungaged locations, (2) identify any trends in streamflow, and (3) attempt to determine the cause of any trends detected.

Status. Because other goals and objectives had a higher priority for the funding available, efforts toward this objective have been minimal.

\section{Objective 2}

Utilize the streamflow information available in the NWIS database to determine regional streamflow characteristics based on the methodology developed in Objective 1. These analyses will produce, at a minimum, streamflow statistics (mean and median streamflows, streamflow per unit area, low flows, peak flows, and trends), as well as explanatory causes and effects, if possible. This objective also includes an assessment of the adequacy of the streamgage network in the region to provide both the data to conduct these types of assessments and predictive equations for estimating streamflow at ungaged sites. When these regional assessments have been completed nationwide, they will be compiled, a national synthesis will be produced, and the process will begin again.

Status. The USGS has been developing a "point-and-click" tool that, as equations become available, will provide the ability to select any location on any river in the country and obtain estimates of the streamflow characteristics at that location. This tool, called StreamStats, has been or is currently being implemented in 34 states. Much additional work is needed to update regression equations for estimating flow at ungaged locations and to implement StreamStats nationwide. Because other goals and objectives had a higher priority for the funding available, efforts toward this objective beyond implementing StreamStats have been minimal.

\section{Goal 4: Expanded Data Collection During Floods and Droughts}

Maximizing data collection prior to, during, and following both floods and droughts is critical to improving our understanding of and predictive capability with regard to hydrologic extremes. The spatial and temporal scales at which streamflow information is collected during extreme events need to be expanded. In addition, new and creative analysis techniques must be utilized. The new techniques will improve our understanding of floods and droughts and the risks they pose to life and property. The ultimate goal is to improve the prediction of extreme events with improved accuracy and increased lead time.

\section{Objective}

Increase the intensity of data collection, improve data analysis, and produce interpretive reports to improve the understanding of, and response to, floods and droughts.

Status. Although few NSIP funds have been available to invest in enhanced data collection during floods and droughts, the NSIP has been able to provide funds for analyses of existing flood data. These efforts have provided increased understanding of floods and their occurrence through reports such as O'Connor and Costa (2003), O'Connor and Costa (2004), Perry (2005), and Costa and Jarrett (2008).

In addition, the USGS has been a leader in applying hydroacoustics technology for use in measuring streamflow. Although hydroacoustics can be used to measure much more than flood flows, this technology allows flood measurements to be made much more quickly and safely, thereby allowing additional measurements to be made. This also results in more accurate flood-flow estimates because flows at fewer locations need to be estimated by non-measurement techniques.

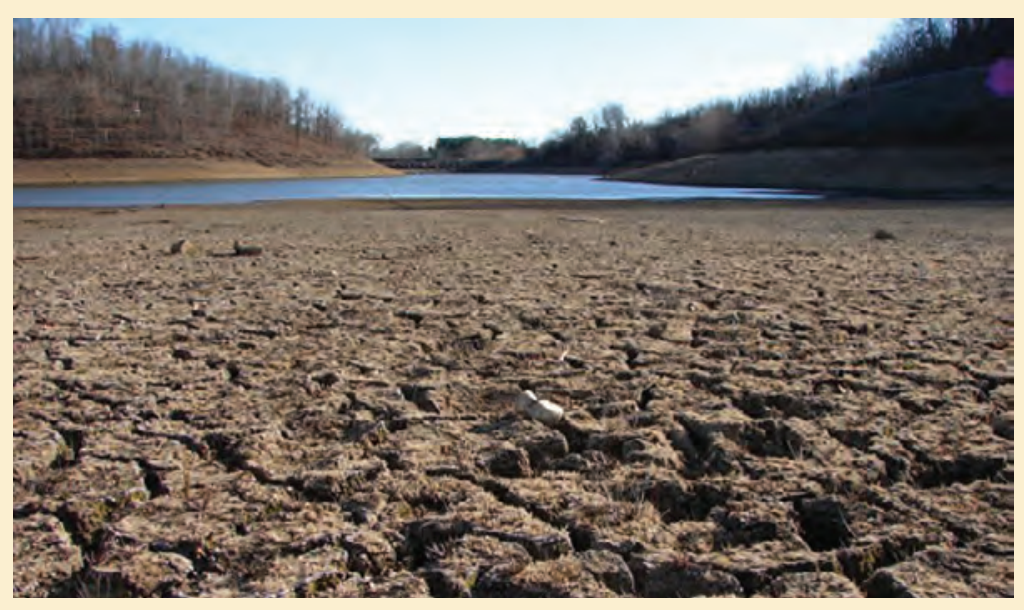

Severe drought. Data from the streamgage network are used to help predict droughts, define their extent, and provide information on recovery. 


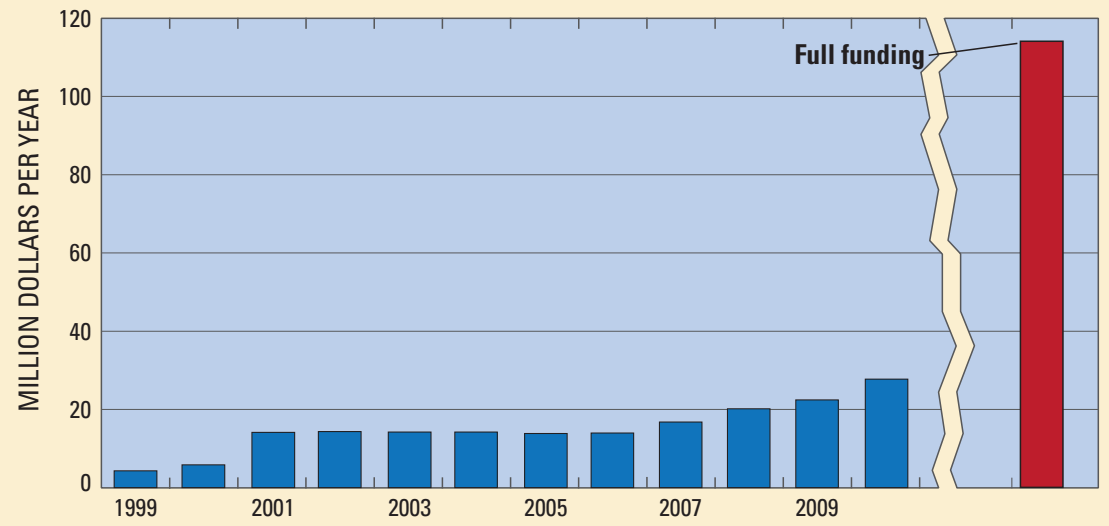

Figure 4. Annual National Streamflow Information Program funding, 1999-2010 Full funding for the program would require $\$ 117$ million per year.

\section{Goal 5: Research and Development}

In many cases, the collection of streamflow data today is much the same as it was in 1889, when the first USGS streamgage began operation. Recent technological advances have provided new tools that allow the USGS to do a more efficient, more effective job of obtaining the streamflow information required for the safety and well-being of the Nation. Continued research and development of new tools, technologies, and methodologies will minimize cost increases while improving data quantity and quality.

\section{Objective}

Perform basic and applied research to develop new tools and technologies that (1) improve the way surface-water information is obtained and analyzed and (2) improve the understanding of surface-water flow. It is expected that this research will be conducted by scientists within and outside the USGS.

Status. Although only minimal NSIP resources have been applied to this objective to date, the USGS has made significant progress in the application of hydroacoustic instruments for the measurement of streamflow. The USGS has worked closely with hydroacoustic instrument vendors to further the development of hydroacoustic instruments to meet the USGS's operational needs for streamflow measurements in a variety of physical settings. The USGS is viewed as the world leader in the application of hydroacoustic technology to the measurement of streamflow. In addition, the USGS used radars in a series of "proof-of-concept" experiments to measure stream discharge directly and with no physical contact with the water. The experiments showed that it was possible to measure streamflow in this manner, but that technological advances would be required to utilize the technique in many locations.

\section{Future Priorities}

Currently (2011), the NSIP is funded at about \$27.7M (fig. 4). The complete program is estimated to require about $\$ 117$ million per year. The majority of any new funds received will be targeted toward stabilizing and furthering the implementation of the streamgage network in support of the five critical Federal streamflow-information needs. The USGS will give a high priority to maintaining an awareness of, and attentiveness to, the needs and expectations of partner agencies, advancing technologies, and additional uses to which the streamflow information can be applied.

\section{References Cited}

Costa, J.E., and Jarrett, R.D., 2008, An evaluation of selected extraordinary floods in the United States reported by the U.S. Geological Survey and implications for future advancement of flood science: U.S. Geological Survey Scientific Investigations Report 20085164, 232 p., available at http://pubs. usgs.gov/sir/2008/5164/.

O'Connor, J.E., and Costa, J.E., 2003, Large floods in the United States: Where they happen and why: U.S. Geological Survey Circular 1245, 19 p., available at http://pubs.usgs.gov/ circ/2003/circ1245/.

O'Connor, J.E., and Costa, J.E., 2004, The world's largest floods, past and present: Their causes and magnitudes: U.S. Geological Survey Circular 1254, 13 p., available at http://pubs.usgs.gov/ circ/2004/circ1254/.

Perry, C.A., 2005, Summary of significant floods in the United States and Puerto Rico, 1994 through 1998 water years: U.S. Geological Survey Scientific Investigations Report 2005-5194, 327 p., available at http://pubs.usgs. gov/sir/2005/5194/.

U.S. Geological Survey, 1999, Streamflow information for the next century: A plan for the National Streamflow Information Program of the U.S. Geological Survey: U.S. Geological Survey Open-File Report 99-456, 13 p., available at http://pubs.usgs.gov/ of/1999/ofr99456/

\section{by J. Michael Norris}

For additional information, please visit: http://water.usgs.gov/nsip/

Or contact:

Mike Norris, Coordinator National Streamflow Information Program mnorris@usgs.gov 